\title{
Should the science communication community play a role in political activism?
}

\section{Joseph Roche and Nicola Davis}

Abstract

Keywords
This letter reflects on how the role of science in society evolved in 2016. While there were plenty of groundbreaking scientific discoveries, the shifting political landscape cultivated a tempestuous relationship between science and society. We discuss these developments and the potential role of the science communication community in political activism.

Community action; Public perception of science and technology; Science and policy-making

2016 was a difficult year for science. Political voices distrusting the scientific method and evidence-based policy seemed to grow louder and more incessant throughout the year. The role of science in society has evolved and, not for the first time, its future is veiled in uncertainty. Natural philosophy was once a privilege of the upper classes in ancient and medieval times before the age of enlightenment laid the foundations for modern science to become integral to society [Grant, 2007]. Has 2016 signalled a sea change in the relationship between science and society? Will science once again be regarded with suspicion by a society that feels excluded from its practice and is apathetic about its benefits?

Such a question might seem outlandish in a period of our history where science and technology are more pertinent and accessible than ever before. Scientific breakthroughs continued unabated in 2016. They included, to name but a few, the detection of gravitational waves [Abbott et al., 2016], the unearthing of a feathered dinosaur tail preserved in amber [Xing et al., 2016], the successful landing of a reusable rocket [Cofield, 2016] and the discovery of an Earth-like planet orbiting the star closest to our Sun [Anglada-Escudé et al., 2016]. These advancements were stunning in and of themselves but also raised expectations for what might be achieved in the coming years.

Tempering these achievements however, was the global rise of anti-establishment populism that has rocked the foundations upon which societal faith in science is built. This was most obvious in the western world where, in April of 2016, Austria came close to becoming the first west European state to elect a far-right leader since World War II. Any lingering hopes that faith in science might remain unaffected by shifting diplomatic landscapes in 2016 were quickly trampled. In June the "Brexit" political juggernaut ploughed straight through the doubts and concerns of the scientific community as the United Kingdom decisively voted to leave the 
European Union [Ward, 2016]. The ill-feeling towards scientists and other traditionally trusted voices in society was perhaps best captured by Michael Gove's assertion that "people in this country have had enough of experts" [Mance, 2016].

This trend of scepticism towards science continued as a fractious United States presidential election lumbered to a clumsy conclusion in November. The majority of university scientists in the U.S. are democrats and the last time a republican president held office there was a dearth of scientists willing to put themselves forward for the post of scientific advisor. When a democrat finally took on the position, "he was excoriated by his peers and excommunicated from some scientific circles" [Stilgoe and Pielke, 2016]. Scientists in the U.S. must now find a way to work with an administration that openly refutes scientific evidence on climate change. Sadly, and fittingly, Oxford Dictionaries declared "post-truth" to be its international word of 2016. When "objective facts are less influential in shaping public opinion than appeals to emotion and personal belief" [Midgley, 2016], what can scientists do to protect the integrity of their field?

There have been notable recent examples of scientists gravitating towards political activism [Lemonick, 2016; Marris, 2016]. Perhaps the most high-profile protest was in response to "House Bill 2". This bill, passed in the U.S. state of North Carolina in March 2016, removes nondiscrimination protections for transgender people by stating that individuals may only use restrooms and changing facilities that correspond to the sex on their birth certificates [General Assembly of North Carolina, 2016]. The science communication community reacted promptly to this legislation, with the Citizen Science Association pulling its 2017 conference from the state [Newman, 2016]. A precedent was then set when some of the largest technology companies in the world also threatened to boycott the state [Chmielewski, 2016]. As other U.S. states prepare to bring in similar legislation in 2017 [Graham, 2017], will the same companies continue to stand up for human rights by threatening to boycott those states too? Will their boycotts extend to other countries?

Many of the companies that threatened to boycott North Carolina have their European headquarters in Ireland [Pinder, 2016] which has one of the most restrictive abortion laws in the world and has been called upon by the United Nations to reform its abortion legislation as it violates human rights [Gentleman, 2016]. Should the science communication community be lobbying those companies to boycott Ireland too? Is it not our responsibility to call out inequality in whatever form we encounter it, be it social inequality, oppression of cultural groups, violence against women or any other threats to democracy? This might seem like an easy choice for academics, researchers and journalists that have job security. But for early-career scientists, students and freelancers, what is the best way to balance political activism and self-preservation?

In 2017 there will be major elections taking place in Germany, France and Holland, as well as further political instability worldwide. We write this letter in the hope of starting a debate among the science communication community about our potential role in political activism. As junior academics in the field we continually find ourselves advising undergraduate and postgraduate science students on their value to society, as well as their responsibilities. These students are often fearful for their future career options. In the current political climate they see only troubled 
waters ahead and are eager for reassurance that the ship can be steadied. We appeal to the senior members of the science communication community to become even more vocal with your advice and guidance - use your experience to help us navigate through these turbulent times for science in society and help ensure that we are strong enough to stay the course.

\section{References}

Abbott, B. P. et al. (2016). 'Observation of Gravitational Waves from a Binary Black Hole Merger'. Physical Review Letters 116 (6), p. 061102.

DOI: 10.1103/PhysRevLett.116.061102.

Anglada-Escudé, G., Amado, P. J., Barnes, J., Berdiñas, Z. M., Butler, R. P., Coleman, G. A. L., Cueva, I. de la, Dreizler, S., Endl, M., Giesers, B., Jeffers, S. V., Jenkins, J. S., Jones, H. R. A., Kiraga, M., Kürster, M., López-González, M. J., Marvin, C. J., Morales, N., Morin, J., Nelson, R. P., Ortiz, J. L., Ofir, A., Paardekooper, S.-J., Reiners, A., Rodríguez, E., Rodríguez-López, C., Sarmiento, L. F., Strachan, J. P., Tsapras, Y., Tuomi, M. and Zechmeister, M. (2016). 'A terrestrial planet candidate in a temperate orbit around Proxima Centauri'. Nature 536 (7617), pp. 437-440. DOI: 10.1038/nature19106.

Chmielewski, D. (8th July 2016). 'The 68 companies (including Apple) that are taking North Carolina's anti-LGBT law to court'. Recode.

URL: http://www.recode.net/2016/7/8/12128698/apple-cisco-intel-sales force-68-companies-north-carolina-anti-lgbt-law-hb2.

Cofield, C. (8th April 2016). 'SpaceX Sticks a Rocket Landing at Sea in Historic First'. Space.com. URL: http://www. space.com/32517-spacex-sticks-rocket-1 anding-sea-dragon-launch.html.

General Assembly of North Carolina (2016). An Act to Provide for Single Sex Multiple Occupancy Bathroom and Changing Facilities in Schools and Public Agencies and to Create Statewide Consistency in Regulation of Employment and Public Accommodations. House Bill 2. Session Law 2016-3.

Gentleman, A. (9th June 2016). 'UN calls on Ireland to reform abortion laws after landmark ruling'. The Guardian. URL: https : //www . theguardian. com/world/20 16/jun/09/ireland-abortion-laws-violated-human-rights-says-un.

Graham, D. A. (9th January 2017). 'What's Behind the New Wave of Transgender 'Bathroom Bills". The Atlantic.

URL: https://www. theatlantic.com/politics/archive/2017/01/states-see -a-new-wave-of-transgender-bathroom-bills/512453/.

Grant, E. (2007). A history of natural philosophy: From the ancient world to the nineteenth century. Cambridge University Press.

Lemonick, M. D. (6th December 2016). 'An Open Letter from Scientists to President-Elect Trump on Climate Change'. Scientific American. URL: https://blogs.scientificamerican.com/observations/an-open-lette r-from-scientists-to-president-elect-trump-on-climate-change/.

Mance, H. (3rd June 2016). 'Britain has had enough of experts, says Gove'. Financial Times.

URL: https://www .ft. com/content/3be49734-29cb-11e6-83e4-abc22d5d108c.

Marris, E. (13th December 2016). 'Is Donald Trump pushing more scientists towards political activism?' Nature. DOI: 10.1038/nature.2016.21130.

Midgley, N. (2016). 'Word of the Year 2016 is...' In: Oxford Dictionaries. URL: https ://en.oxforddictionaries.com/word-of-the-year/word-of-the-year-2016. 
Newman, G. (26th May 2016). 'In support of our core values: A conference decision'. Citizen Science Association. URL: http://citizenscience.org/2016/0 5/26/in-support-of-our-core-values-a-conference-decision.

Pinder, S. (20th May 2016). 'Ireland's Top 1000 Companies Record High $€ 36$ Billion in 2015'. Business World. URL: http://www. businessworld. ie/economy/Ireland -s-Top-1000-companies-record-high-36-billion-in-2015-564272.html.

Stilgoe, J. and Pielke Jr., R. (11th November 2016). 'They may not like it, but scientists must work with Donald Trump'. The Guardian. URL: https : //www . the guardian.com/science/political-science/2016/nov/11/they-may-not-lik e-it-but-scientists-must-work-with-donald-trump.

Ward, B. (24th June 2016). “"Brexit” Could Do Real Damage to U.K. Science'. Scientific American. URL: https://blogs.scientificamerican.com/guest-blog /brexit-could-do-real-damage-to-u-k-science/.

Xing, L., McKellar, R. C., Xu, X., Li, G., Bai, M., Persons, W. S., Miyashita, T., Benton, M. J., Zhang, J., Wolfe, A. P., Yi, Q., Tseng, K., Ran, H. and Currie, P. J. (2016). 'A Feathered Dinosaur Tail with Primitive Plumage Trapped in Mid-Cretaceous Amber'. Current Biology 26 (24), pp. 3352-3360. DOI: $10.1016 / j$.cub. 2016.10.008.

Dr Joseph Roche is an Astrophysicist and Assistant Professor in Science Education at Trinity College Dublin. He teaches Science \& Society and Communicating Science on a Master in Science Education programme. His research area is the role of science in society. E-mail: Joseph.Roche@tcd.ie.

Nicola Davis is a Neuroscientist and has worked as a researcher in Trinity College Dublin, Goettingen University and Imperial College London. She has developed and coordinated national and European-funded public engagement events for the School of Education at Trinity College. E-mail: davisni@tcd.ie.

\section{How to cite}

Roche, J. and Davis, N. (2017). 'Should the science communication community play a role in political activism?'. JCOM 16 (01), L01. 